EGU2020-22413, updated on 09 May 2020

https://doi.org/10.5194/egusphere-egu2020-22413

EGU General Assembly 2020

(c) Author(s) 2020. This work is distributed under

the Creative Commons Attribution 4.0 License.

\title{
Heritage Building Stones from Évora, Portugal
}

\author{
Luis Lopes \\ Instituto de Ciências da Terra, Universidade de Évora, Évora, Portugal (lopes@uevora.pt)
}

The city of Évora, a World Heritage Site recognized by UNESCO in 1986, also owes this recognition to the stones that built its monuments and preserve them until today.

This work brings together the contributions that we have gathered over the past three decades and allow us to have a very complete idea, not only about the materials used in the hundreds of monuments and historic buildings but also about their provenance. If some materials are so emblematic that they allow an immediate identification with the naked eye, others needed more sophisticated and precise techniques so that there was no doubt about their origin.

The igneous rocks and gneisses of granite composition are part of the "Massif of Évora" on which the city is built. Thus, and quite naturally they are by far the most represented group in monuments from all historical periods. Its function is essentially structural, but there are also functional, ornamental and decorative objects. For example, the oldest megalithic structures found in the vicinity of the city are made up of large granite blocks that often had to be transported to their locations.

On the other hand, many gargoyles and statues that decorate the churches are also made up of these granite rocks. On these, the natural erosion of centuries of exposure to the environment has led to a state of alteration, sometimes very accentuated, which would justify its replacement by replicas sculpted in similar rocks. Provenance studies have made it possible to identify old quarries in the vicinity of the city where, on the one hand, the ancient rock extraction techniques can be observed and on the other hand, they allow the obtaining of the raw material necessary for these restoration and conservation works. In any case, they are places that need to be inventoried and protected, with the municipality already aware of their existence.

As well as the monuments of the Roman Period, also the structures of the Medieval Period, such as the city walls, the Cathedral (started to be built in $1186 \mathrm{AD}$ ) and all the great churches, were also built with these granitoids.

In addition to these rocks, many others of multiple varieties and origins are present. The marbles, especially the Estremoz Marbles (Global Heritage Stone Resource), are ubiquitous in the city, but there are also emblematic marbles from other places, some easily identifiable (ie Viana do Alentejo, Escoural, Trigaches, Serpa and Vila Verde de Ficalho, for presenting mineralogy, textures, colors and patterns which, together with more recent analytical techniques, have confirmed its provenance. 
Sedimentary rocks, with emphasis on Portuguese Mesozoic limestones, ie Lioz - GHSR and Brecha da Arrábida - GHSR candidate, among others more rare and with very specific use in ornamental details, are also present and contribute to enrich a heritage in stone that makes this city so special and very popular with tourists of all nationalities.

Acknowledgments: the authors thank to FCT for funding the ICT (UID/GEO/04683/2019), as well as COMPETE POCI-01-0145-FEDER-007690. 